\title{
Persistence of the exotic kelp Undaria pinnatifida does not depend on sea urchin grazing
}

\author{
Joseph P. Valentine*, Craig R. Johnson \\ School of Zoology and Tasmanian Aquaculture and Fisheries Institute, University of Tasmania, GPO Box 252-05, Hobart, \\ Tasmania 7001, Australia
}

\begin{abstract}
We investigated mechanisms enabling persistence of the introduced Asian kelp Undaria pinnatifida on the sea urchin (Heliocidaris erythrogramma) 'barrens' on the east coast of Tasmania. Development of dense stands of $U$. pinnatifida requires disturbance to reduce the cover of native algae. Observations of $U$. pinnatifida occurring abundantly on sea urchin barrens suggests that disturbance in the form of grazing by sea urchins prevents recovery of native canopy-forming species, allowing dense stands of $U$. pinnatifida to persist. We examined this hypothesis over a $30 \mathrm{mo}$ period in a manipulative experiment in which the response of native algae and $U$. pinnatifida was examined in treatments comprising all possible combinations of +/- urchins, +/- U. pinnatifida and +/enhanced native algal spore inoculum. The results demonstrated that the sea urchin $H$. erythrogramma can have a significant impact on $U$. pinnatifida abundance. The response was most dramatic in the 2001 sporophyte growth season, when sea urchins destructively grazed U. pinnatifida sporophytes in experimental plots on the urchin barren. In other years, when there was higher recruitment of $U$. pinnatifida sporophytes, urchins reduced sporophyte abundance but did not prevent development of a $U$. pinnatifida canopy. Removal of sea urchins resulted in a slow increase in cover of understorey red algae, but only limited recovery of native canopy-forming species. In treatments where both sea urchins and $U$. pinnatifida were removed, cover of canopy-forming species did not exceed $6 \%$ over the duration of the study. Thus, in the absence of sea urchin grazing, there was no evidence of inhibition of $U$. pinnatifida by native algae. While the intensity of sea urchin grazing may directly influence the extent of the $U$. pinnatifida canopy, recovery of native canopyforming species was apparently influenced by a combination of factors including seaurchin grazing, depth and, most importantly, the degree of sediment accumulation on the rocky substratum. The manipulations showed that removal of the factor (i.e. sea urchin grazing) that ostensibly facilitated replacement of native canopy-forming algae by $U$. pinnatifida did not realise recovery of native canopy-forming species.
\end{abstract}

KEY WORDS: Invasion processes $\cdot$ Introduced macroalgae $\cdot$ Persistence $\cdot$ Disturbance $\cdot$ Sea urchin grazing $\cdot$ Canopy-forming algae $\cdot$ Undaria pinnatifida

\section{INTRODUCTION}

Biological introductions in the marine environment have increased significantly over the last 2 decades, mainly due to human-assisted transport associated with international shipping, aquaculture and aquarium activities (Carlton \& Geller 1993, Meinesz et al. 1993, Ribera \& Boudouresque 1995, Carlton 1999). Introduced marine species now represent a major threat to native ecosystems with the potential to dramatically alter native communities by affecting biological diversity, productivity, habitat structure and fisheries (Carlton 1999).

In defining the threat that an introduced species poses to native communities, it is important to understand the role of disturbance in the invasion process (Hiebert 1997, Valentine \& Johnson 2003). If an introduced species can establish and maintain persistent populations in the absence of disturbance, it poten- 
tially represents a major threat to the integrity of native communities. Conversely, if establishment and persistence of an exotic species relies on disturbance, the key threatening process may be the disturbance rather than the introduced species itself.

While disturbance may facilitate establishment of an introduced species, its continued persistence may not require ongoing disturbance. For example, on the Atlantic coast of Canada, invasion by the introduced seaweed Codium fragile spp. tomentosoides is facilitated by disturbance to the native kelp canopy in the form of either destructive urchin grazing or smothering of kelp laminae by the epiphytic bryozoan Membranipora membranacea (Chapman et al. 2002). Once C. fragile is established, however, it effectively displaces native species by inhibiting their recruitment (Chapman et al. 2002). Similarly, invasion of San Francisco Bay by the introduced clam Potamocorbula amurensis, following a major flood disturbance, inhibited recovery of the native benthic community during conditions of normal river flow (Nichols et al. 1990).

Since its introduction to the port of Triabunna in the 1980s (Sanderson \& Barrett 1989, Nichols et al. 1990, Reusch \& Williams 1999), the annual Japanese kelp Undaria pinnatifida has become a conspicuous feature of subtidal communities in sheltered to moderately exposed habitats along much of the east coast of Tasmania. Recent experiments have clearly demonstrated that disturbance to the native algal canopy is an essential process facilitating successful establishment of $U$. pinnatifida sporophytes at high densities. Following both experimental canopy removal (Valentine \& Johnson 2003) and natural canopy disruption (Valentine \& Johnson 2004), U. pinnatifida sporophytes recruited at high densities, while the presence of an intact native canopy in adjacent control sites inhibited sporophyte development .

While the above recent experiments are illuminating in defining mechanisms of establishment, factors responsible for the persistence of dense Undaria pinnatifida stands have not been adequately addressed. Sea urchin grazing may represent a continuous source of disturbance that effectively maintains dense $U$. pinnatifida stands. In Tasmania, $U$. pinnatifida occurs most abundantly on sea urchin 'barrens' characterised by high densities of the sea urchin Heliocidaris erythrogramma, low cover of native algae and seasonal abundance of $U$. pinnatifida, which often attains $100 \%$ cover (Sanderson \& Barrett 1989, Sanderson 1997, Johnson et al. 2004. It has been suggested that $U$. pinnatifida maintains high densities of sporophytes on urchin barrens as a result of high reproductive output and rapid spring growth, which exceeds the grazing capabilities of the urchin (Sanderson \& Barrett 1989). Based on these observations and the role of sea urchins as a major source of disturbance to temperate subtidal communities elsewhere (Mann 1977, Schiel \& Foster 1986, Chapman \& Johnson 1990, Andrew 1993, Hagen 1995, Palacin et al. 1998), our hypothesis is that maintenance of dense stands of $U$. pinnatifida on urchin barrens requires continuous disturbance in the form of intensive grazing by sea urchins.

In this study, we report on a large manipulative experiment designed to identify (1) whether dense stands of Undaria pinnatifida are self-maintaining in the absence of high densities of sea urchins and (2) those factors that affect the re-establishment of native canopyforming species in areas dominated by sea urchins Heliocidaris erythrogramma and U. pinnatifida.

\section{MATERIALS AND METHODS}

Study site. The study was conducted between June 1999 and November 2001 in the Mercury Passage, on the east coast of Tasmania. In this area, a variety of subtidal communities are found, ranging from sea urchin 'barrens' to habitats dominated by native perennial brown algae. We conducted the experiment in an extensive area of urchin barren habitat on a gently sloping reef at Lords Bluff in the Mercury Passage $\left(42^{\circ} 31^{\prime} \mathrm{S}, 147^{\circ} 59^{\prime} \mathrm{E}\right)$. At this site, a narrow fringe of native algae (consisting of a range of species including Phyllospora comosa, Ecklonia radiata, Sargassum spp. and Cystophora spp.) extends from the sublittoral fringe to approximately $5 \mathrm{~m}$ depth. At depths greater than $5 \mathrm{~m}$, sea urchin barrens (sea urchin densities 4 to $8 \mathrm{~m}^{-2}$ ) dominate community structure, extending $>100 \mathrm{~m}$ offshore to the limit of available substratum (12 $\mathrm{m}$ depth). While we have no quantitative data on the algal community at this site prior to urchin barren formation, interviews with commercial divers and information from admiralty charts indicate that native canopy-forming algae previously dominated the area.

Experimental design. The experiment consisted of 8 treatments, with factorial combinations of 3 factors: (1) abundance of Heliocidaris erythrogramma (2 levels; presence/absence), (2) extent of Undaria pinnatifida canopy (2 levels; presence/absence of sporophytes) and (3) level of native algal spore inoculum (2 levels; background/enhanced).

Each experimental treatment had 4 replicates, yielding a total of 32 plots. Experimental plots were randomly distributed along approximately $250 \mathrm{~m}$ of coastline in the 7 to $12 \mathrm{~m}$ depth range, with a minimum separation of $15 \mathrm{~m}$ between each plot. Treatments were assigned at random to permanent plots in June 1999. The experimental plots were $4 \times 4 \mathrm{~m}$, although response variables were estimated from the inner $2 \times$ $2 \mathrm{~m}$ area to minimise edge effects. 
Manipulations. The initial removal of sea urchins Heliocidaris erythrogramma commenced in June 1999. Thereafter, plots were maintained clear of immigrating urchins every 4 to $6 \mathrm{wk}$ for the 30 mo duration of the experiment. Fences were not used to restrict urchin access since $H$. erythrogramma showed low rates of movement in an earlier study conducted on a nearby reef (Sanderson et al. 1996) and in a pilot study we conducted to assess immigration rates.

Undaria pinnatifida sporophytes were removed by cutting plants immediately above the holdfast. In the first season of the experiment (1999), plants were removed once they could be readily identified as $U$. pinnatifida recruits, at approximately $5 \mathrm{~cm}$ total length. Removing plants at this small size was prohibitively time consuming, so in subsequent seasons (2000 and 2001), plants were removed once they reached $15 \mathrm{~cm}$ in length. Removals were conducted approximately monthly during the $U$. pinnatifida sporophyte growth season (i.e. August to December).

The native algal spore inoculum was enhanced by placing fertile native species collected from an adjacent reef in mesh bags attached to 2 metal stakes placed on the opposite corners of experimental plots (4 bags plot $^{-1}$ ). Stakes were placed on the perimeter of the plots (rather than in the centre) to minimise disturbance. Several individuals (6 to 10 depending on the species and size of plants) of a single species were placed in each mesh bag. This technique has proved effective in seeding macroalgae in other experiments (Dayton et al. 1984). A range of canopy-forming brown algae (Phyllospora comosa, Ecklonia radiata, Carpoglossum confluens, Seirococcus axillaris) were used for the seeding treatment depending on their availability and the presence of fertile reproductive material. Fresh material was added to experimental plots every 6 to 8 wk during 1999 and 2000. In addition to using plants in mesh bags for the enhancement treatment, algae transplanted to concrete bricks were also used as a spore source (Macrocystis pyrifera and Ecklonia radiata). For algal transplants, whole plants were carefully removed from the substratum, attached to bricks using heavy-duty rubber bands and evenly spaced along the perimeter of plots (4 plants plot $^{-1}$ for each species). Plots were separated by a minimum distance of $15 \mathrm{~m}$ to ensure separation of treatments receiving an enhanced spore inoculum from those that did not receive the enhancement. We assumed that the effective spore shadow of the algal species we used was limited to $<15 \mathrm{~m}$, as has been demonstrated for other large brown algae (Anderson \& North 1966, Ambrose \& Nelson 1982, Deysher \& Norton 1982, Andrew \& Viejo 1998). Species used in the spore enhancement treatments and the dates of replenishment of fresh material are included in Table 1.
Table 1. Details of spore-enhancement manipulations, indicating the species 'seeded', the enhancement technique and dates of deployment. Mesh bag: hanging mesh bags containing reproductive plants over the plot. Transplant: reproductive plants transplanted to the perimeter of plots

\begin{tabular}{|c|c|c|}
\hline $\begin{array}{l}\text { Enhancement } \\
\text { methodology }\end{array}$ & $\begin{array}{c}\text { Date } \\
\text { conducted }\end{array}$ & Species 'seeded' \\
\hline \multirow[t]{8}{*}{ Mesh bag } & 26/6/99 & $\begin{array}{l}\text { Seirococcus axillaris, } \\
\text { Carpoglossum confluens, } \\
\text { Ecklonia radiata }\end{array}$ \\
\hline & $4 / 8 / 99$ & $\begin{array}{l}\text { Seirococcus axillaris, } \\
\text { Carpoglossum confluens, } \\
\text { Ecklonia radiata }\end{array}$ \\
\hline & 8/11/99 & $\begin{array}{l}\text { Seirococcus axillaris, } \\
\text { Carpoglossum confluens, } \\
\text { Ecklonia radiata }\end{array}$ \\
\hline & $14 / 1 / 00$ & $\begin{array}{l}\text { Ecklonia radiata, } \\
\text { Phyllospora comosa }\end{array}$ \\
\hline & $22 / 3 / 00$ & $\begin{array}{l}\text { Ecklonia radiata, } \\
\text { Phyllospora comosa }\end{array}$ \\
\hline & $23 / 6 / 00$ & $\begin{array}{l}\text { Seirococcus axillaris, } \\
\text { Carpoglossum confluens, } \\
\text { Ecklonia radiata }\end{array}$ \\
\hline & $21 / 9 / 00$ & $\begin{array}{l}\text { Seirococcus axillaris, } \\
\text { Carpoglossum confluens, } \\
\text { Ecklonia radiata }\end{array}$ \\
\hline & $20 / 11 / 00$ & $\begin{array}{l}\text { Seirococcus axillaris, } \\
\text { Carpoglossum confluens, } \\
\text { Ecklonia radiata }\end{array}$ \\
\hline \multirow[t]{2}{*}{ Transplant } & $13 / 4 / 00$ & Ecklonia radiata \\
\hline & $10-11 / 5 / 00$ & Macrocystis pyrifera \\
\hline
\end{tabular}

Algal assessment. Assessment of experimental plots was conducted approximately every $3 \mathrm{mo}$, during which the density of canopy-forming species and urchins was recorded, along with cover of understorey algae, sessile invertebrates and sediment. A census of the density of canopy-forming algae $(>30 \mathrm{~cm}$ total length) and urchins was made by direct counts in the inner $2 \times 2 \mathrm{~m}$ of each plot. Cover of understorey species was estimated from five $0.10 \mathrm{~m}^{2}$ photoquadrats positioned randomly in each plot. Photographs were taken using Ektachrome 100 ASA slide film and slides were converted to digital format before scanning to determine algal cover using a point intercept method. Each image was overlayed with 100 equally spaced dots using Imagepro ${ }^{\circledR}$ software. Organisms were identified from photographs to the highest taxonomic resolution possible. For large brown algae, identification to species level was possible; however, for most of the understorey species, photographs could only be used to separate algal cover into guilds (e.g. red algae, brown turf algae, green algae). An estimate of sediment depth was also obtained during algal assessments, measured to the nearest millimetre in 5 randomly determined positions in each plot. 
The main limitation associated with photographic sampling is that it does not allow sampling of more than 1 structural layer of the algal community (Foster et al. 1991, Meese \& Tomich 1992, Dethier et al. 1993). When canopy species were present (mainly Undaria pinnatifida), this problem could be largely overcome by moving fronds aside before photographs were taken. When foliose understorey algae were present in a quadrat, however, it was not practical to move them aside to allow quantification of benthic cover beneath. As a consequence of these limitations, analysis was restricted to the dominant components of the understorey community.

At the conclusion of the experiment in November 2001, destructive sampling was conducted to investigate algal community structure in more detail. All foliose macroalgae in each plot were removed by hand and placed in mesh bags before being transported to the laboratory (filamentous algae occurring in the sediment matrix were not collected). Samples were sorted to the highest taxonomic resolution possible and dried $\left(70^{\circ} \mathrm{C}\right.$ for $48 \mathrm{~h}$ ) before weighing.

Statistical analysis. Analysis of the response of the algal community was conducted separately for assessments made in November 2000 and November 2001, approximately 18 and 30 mo after manipulations commenced, respectively. We also analysed the response of Undaria pinnatifida in November 1999 following 6 mo of sea urchin removal. Although assessments of experimental plots were made at least quarterly over the 30 mo duration of the experiment, we decided $a$ priori to conduct separate analyses for the peak period of $U$. pinnatifida sporophyte growth in each year of the experiment (i.e. for assessments made in November), rather than using a repeated measures approach. This set of tests is orthogonal and the approach does not require special assumptions to address problems of non-independence of observations over time. Given no significant differences among plots prior to establishing the treatments, significant differences among any treatments at any one time after the commencement of the experiment are equivalent to a significant 'time $x$ treatment' effect in a repeated measures design.

Of the 5 species that were used in the native spore enhancement treatment, only recruits of Carpoglossum confluens were ever observed in the study area. None of these recruits, however, reached the criterion of $30 \mathrm{~cm}$ minimum length used in density assessments during the course of the experiment and their cover averaged $<1 \%$ across all treatments. We tested whether cover of C. confluens recruits was influenced by the spore enhancement treatment in preliminary analyses using a 4 -factor Model III nested ANOVA. This analysis included main effects of urchin removal, Undaria pinnatifida removal and spore enhancement (all fixed effects) as well as the nested term of 'plots within (urchin $\times$ Undaria $\times$ spore enhancement)' (a random effect). In both November 2000 $(F=1.33 ; \mathrm{df}=1,24 ; \mathrm{p}=0.26)$ and November $2001(F=$ $1.05 ; \mathrm{df}=1,24 ; \mathrm{p}=0.23$ ), the effect of spore enhancement was highly insignificant.

As a consequence of the very low cover values and lack of any effect of spore enhancement, this treatment was ignored in the main analysis, providing greater power to examine the effects of removal of sea urchins and Undaria pinnatifida. For the main analysis, density data were analysed using a 2-factor Model I ANOVA, while for cover data, a 3-factor Model III nested ANOVA was used. Both analyses included treatments of + /- sea urchin and +/-U. pinnatifida. For the nested ANOVA, 'plots within (urchin $\times$ Undaria)' was included as a random factor.

Prior to all univariate tests, transformations to stabilise variances were determined from the relationship between group standard deviations and means (Draper \& Smith 1981). Transformations are expressed in terms of the untransformed variate, $Y$. All univariate tests were undertaken using the $\mathrm{SAS}^{\circledR}$ statistical package. Variances of some variables remained heterogeneous after transformation, which usually occurred when mean abundance (and variance) of a guild was 0 in several experimental plots. In these instances, the analysis was still carried out, recognising that with a balanced design, mild heteroscedasticity usually has little effect on Type I error, but can increase Type II error (Scheffé 1959).

\section{RESULTS}

\section{Maintenance of sea urchin removal treatment}

During the first 18 mo of the experiment, physical removal maintained urchin densities at very low levels in removal treatments, averaging $0.5 \pm 0.11 \mathrm{SE} \mathrm{m}^{-2}$ compared to $7.1 \pm 0.23 \mathrm{SE} \mathrm{m}^{-2}$ in unmanipulated plots (Fig. 1). Between January and April 2001, however, some reinvasion of cleared plots occurred with densities reaching an average of $5.8 \pm 0.62 \mathrm{SE} \mathrm{m}^{-2}$ in April 2001. For the remainder of the experimental period, the number of animals in removal plots remained at very low levels.

\section{Response of Undaria pinnatifida to experimental manipulations}

In each year, Undaria pinnatifida densities were higher in plots from which sea urchins were removed than in plots containing sea urchins (Fig. 2). In urchin removal plots, average densities of $U$. pinnatifida sporophytes were 3 to 4 plants $\mathrm{m}^{-2}$ higher than in con- 


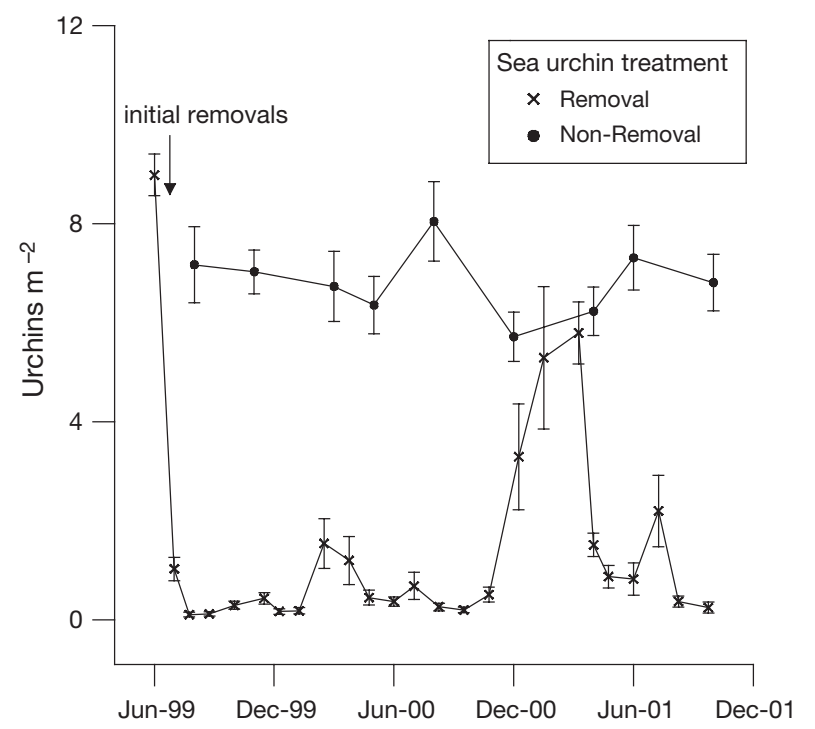

Fig. 1. Heliocidaris erythrogramma. Mean density $( \pm \mathrm{SE})$ of sea urchins in removal and non-removal plots $(\mathrm{n}=16)$. Removal plots were visited approximately every $4 \mathrm{wk}$ for the duration of the study. Data associated with the urchin removal treatment represents the number of animals cleared from plots while maintaining the treatment. For the non-removal treatment, densities are derived from data collected during routine assessments of algae and sea urchins (conducted at 3 monthly intervals)

trols in 1999 and 2000; however, these differences were not statistically significant (1-way ANOVAs, 1999: $F=3.27$, df $=1,14, \mathrm{p}=0.092 ; 2000: F=3.74, \mathrm{df}=1,14$, $\mathrm{p}=0.074)$. In 2001, the effect of urchin removal was statistically significant (1-way ANOVA, $F=8.41$, df = $1,14, \mathrm{p}=0.012)$, resulting in a mean $U$. pinnatifida density of 5.2 plants $\mathrm{m}^{-2}$ compared to less than 0.1 plant $\mathrm{m}^{-2}$ in controls. This result corresponded to an average biomass (dry weight) of $54.5 \mathrm{~g} \mathrm{~m}^{-2} U$. pinnatifida in urchin removal plots and $0.4 \mathrm{~g} \mathrm{~m}^{-2}$ in controls (Fig. 3).

The effect of sea urchins was also evident from the number of Undaria pinnatifida plants taken from removal treatment plots. In all years, there were fewer $U$. pinnatifida plants removed from plots with sea urchins than in treatments free of sea urchins (Table 2).

Table 2. Undaria pinnatifida. Number of plants removed from experimental 'U. pinnatifida removal' plots. In 1999, plants were removed as soon as they could be identified as $U$. pinnatifida (at ca. $5 \mathrm{~cm}$ in total length). In 2000 and 2001, plants were removed on reaching $15 \mathrm{~cm}$ in total length. During each year, plots were visited regularly during the sporophyte growth season (August to December) to remove any new recruits. Data are means $( \pm \mathrm{SE})$

\begin{tabular}{|lccccc|}
\hline \multicolumn{2}{|c}{1999} & \multicolumn{2}{c}{2000} & \multicolumn{2}{c|}{2001} \\
+ urchin & -urchin & +urchin & -urchin & +urchin & -urchin \\
\hline $996 \pm 158.1$ & $1719 \pm 136.3$ & $165 \pm 51.4$ & $217 \pm 44.8$ & $2 \pm 1.0$ & $47 \pm 11.4$ \\
\hline
\end{tabular}

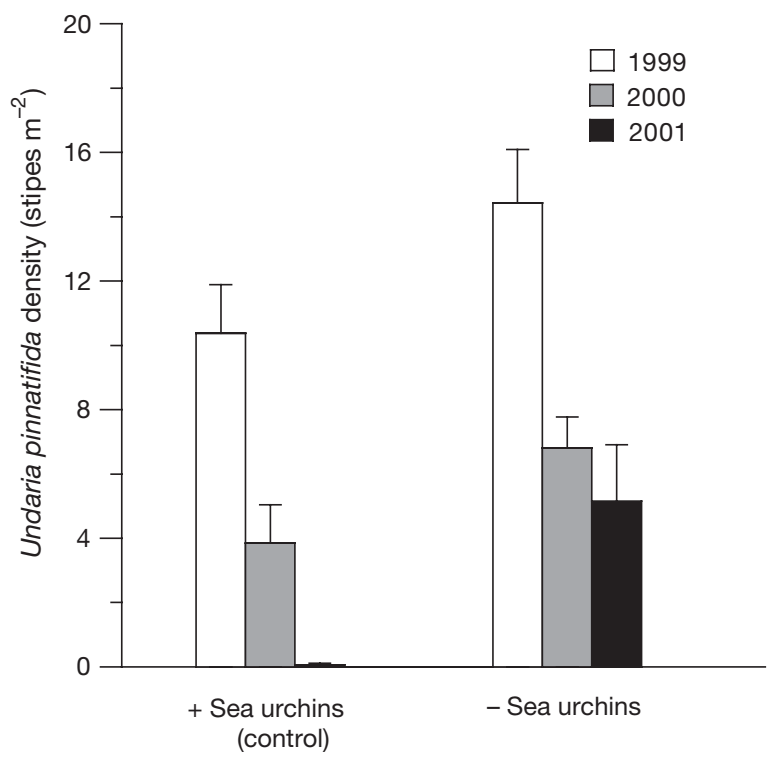

Fig. 2. Undaria pinnatifida. Effect of manipulations of sea urchin densities on the abundance of $U$. pinnatifida assessed in November 1999, 2000 and 2001. Data represent mean $(+\mathrm{SE})$ stipe counts of all adult plants $>30 \mathrm{~cm}$ in size in each $4 \mathrm{~m}^{2}$ experimental plot ( $\mathrm{n}=8$ replicates per treatment). Note that the data do not include treatments from which $U$. pinnatifida was removed

\section{Response of native algae to sea urchin removal}

Total native algal cover

Total native algal cover in plots where sea urchins were not removed remained at $<30 \%$ during the experimental period (Fig. 4). The community was characterised by very low cover of both brown and green algae, and moderate cover of red algae. In these plots, cover of canopy-forming species remained $<2 \%$ throughout the experiment. The persistent presence of a high cover of sediment (average $>50 \%$ ) up to $10 \mathrm{~mm}$ in depth was also a feature of control areas.

A significant increase in cover of native algae was detected in response to removal of sea urchins in both the November 2000 and 2001 assessments (Fig. 4, Table 3). While total algal cover was approximately comparable between urchin removal and non-removal plots for the first year of the study, cover increased steadily in urchin removal treatments after July 2000. This pattern is reflected clearly in the biomass (dry weight) of plants determined at the conclusion of the experiment, with an average of $36.2 \mathrm{~g} \mathrm{~m}^{-2}$ in urchin 


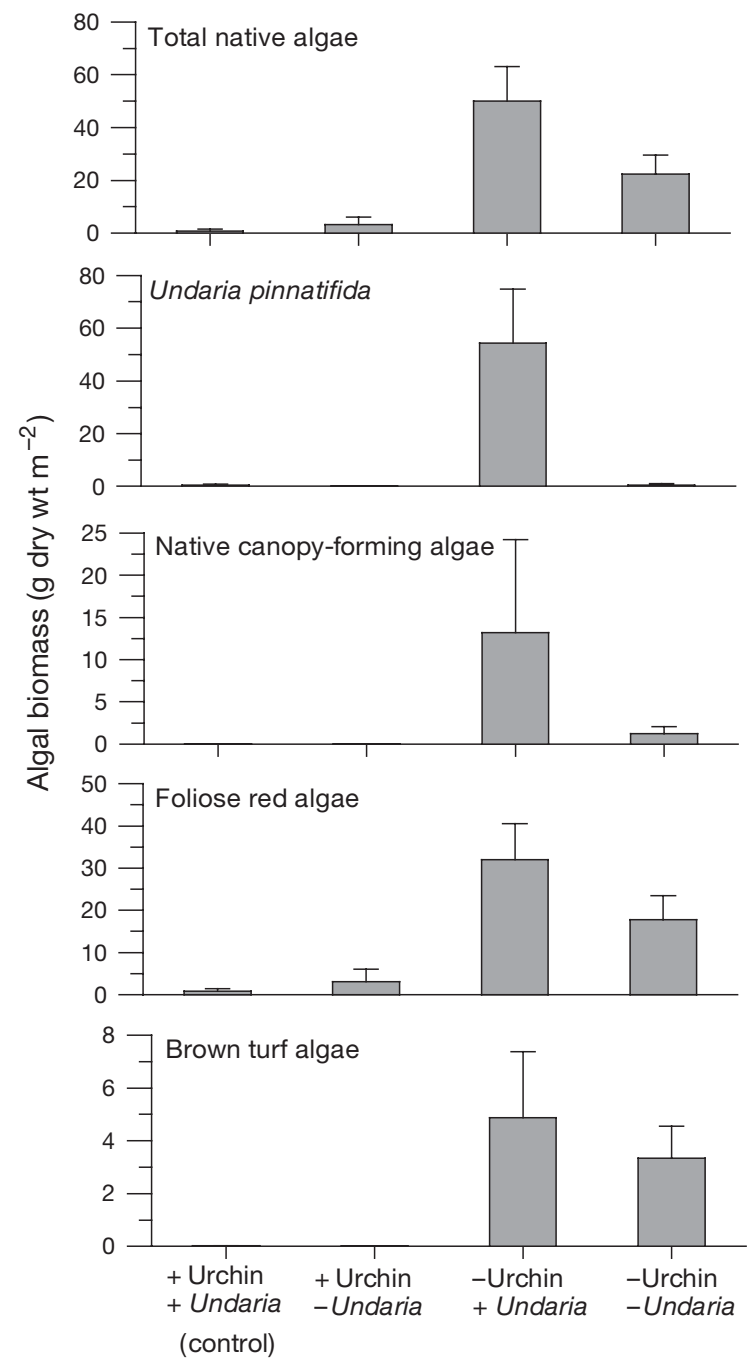

Fig. 3. Heliocidaris erythrogramma and Undaria pinnatifida. Effect of manipulations of sea urchins and the canopy of $U$. pinnatifida on the biomass ( $g$ dry weight $\mathrm{m}^{-2}$ ) of major algal groups following completion of the experiment in November 2001. Data represent means $(+\mathrm{SE})$ for each treatment $(n=8)$. Biomasses were obtained by removing all macroalgae from each experimental plot $\left(4 \mathrm{~m}^{2}\right.$ plot $\left.^{-1}\right)$. Note the different scales on the $y$-axes

removal treatments compared with $<2 \mathrm{~g} \mathrm{~m}^{-2}$ when urchins were present (Fig. 3, Table 4).

\section{Response of native canopy-forming species}

While native canopy-forming species never exceeded $6 \%$ in any treatment over the 30 mo experimental period, significantly greater cover developed in urchin removal plots than in controls in November 2000 (Fig. 4, Table 3). The magnitude of this difference was small, however, with cover increasing from $0.7 \%$ in the presence of urchins to $4.8 \%$ in urchin removal plots. For data collected in November 2001, no canopyforming species were recorded in the presence of urchins, compared with an average of $1.6 \%$ in urchin removal plots. The predominate canopy-forming species that were observed during the study were Cystophora retroflexa and C. moniliformis, as well as occasional individuals of a range of Sargassum species.

Data describing the biomass (dry weight) of canopyforming species at the end of the experimental period exhibited the same trend as cover. Across urchin removal treatments, the biomass of canopy species averaged $7.2 \mathrm{~g} \mathrm{~m}^{-2}$ (Fig. 3). This value was strongly influenced by the presence of a single large Seirococcus axillaris plant, present in 1 of the urchin removal plots at the beginning of the experiment that persisted throughout the study period. If this individual was excluded from the analysis, the average biomass was reduced to $4.1 \mathrm{~g} \mathrm{~m}^{-2}$.

\section{Response of understorey algae}

Sea urchins also had significant effects on the cover of red algae, a guild consisting of both foliose and filamentous species. In November 2000, cover of red algae averaged $14.2 \%$ in the presence of sea urchins, while it increased to $23.5 \%$ in urchin removal plots (Fig. 4, Table 3). By November 2001, there was an even greater difference in the 2 treatments, with cover averaging $14.3 \%$ in the presence of urchins and $41.5 \%$ in urchin removal plots. The temporal trend indicates that the greatest divergence in treatments occurred in the second year after manipulation of urchins commenced (Fig. 4). Native algal cover was clearly dominated by the guild of red understorey algae, which showed stronger interannual variation than seasonal fluctuations.

The biomass (dry weight) of foliose red algae, collected during destructive sampling at the end of the experiment, reflected the patterns observed in cover (Fig. 3, Table 4). Average biomass in urchin removal plots was $24.9 \mathrm{~g} \mathrm{~m}^{-2}$, while in the presence of sea urchins, this value amounted to only $1.9 \mathrm{~g} \mathrm{~m}^{-2}$. The dominant red algal species occurring in urchin removal plots in November 2001 was Dasya ceramioides, which contributed more than $50 \%$ of total algal biomass in urchin removal plots. The biomass of Echinothamnion sp., Dictymenia harveyii and Heterosiphonia spp. also reached moderate levels in urchin removal plots.

In plots where sea urchins were present, the average cover of green algae never exceeded $0.1 \%$. Sea urchin removal resulted in very small but statistically signifi- 
cant increases in cover of green algae in November 2000 and November 2001 (Fig. 4, Table 3). These increases were mainly associated with the presence of Codium spp. or unidentified filamentous algae. Green algae were not collected in sufficient quantity during destructive sampling to warrant analysis.

The guild of brown turf-forming algae did not respond to a decrease in urchin density during the first year of the experiment (assessment in November 2000). A year later, in November 2001, however, the effect of urchins was significant but small, resulting in an additional $3 \%$ cover in removal plots. In destructive samples, no representatives from the brown turf guild were collected in the presence of urchins, while biomass averaged $4.1 \mathrm{~g} \mathrm{~m}^{-2}$ in urchin removal treatments. The main species collected during destructive sampling were Zonaria angustata and Dictyopteris muelleri. Ephemeral species that were absent during destructive sampling, but relatively abundant at various times during the study, included Asperococcus spp., Scytosiphon spp. and Colpomenia spp.

\section{Response of native algae to Undaria pinnatifida removal}

In contrast to responses to urchin removal, manipulation of Undaria pinnatifida had limited effects on native algae. Significant treatment effects due to either $U$. pinnatifida removal or the 'urchin removal $\times$ Undaria removal' interaction were rarely detected, with the exception of brown turf algae (Table 3). Removal of the $U$. pinnatifida canopy resulted in approximately $3 \%$ greater cover of brown turf (data collected in November 2000). A year later, in November 2001, there was no evidence that any algal group responded to the removal of the $U$. pinnatifida canopy.

\section{Effect of experimental manipulations on sediment}

Cover of a sediment matrix was consistently high in all treatments throughout the experiment, averaging

$$
\mathbf{X}_{+}^{+ \text {Urchins }} \bigcirc_{- \text {Undaria }}^{+ \text {Urchins }} \diamond_{+ \text {Undaria }}^{\text {Urchins }} \boldsymbol{\Delta}_{\text {-Undaria }}^{\text {-Urchins }}
$$
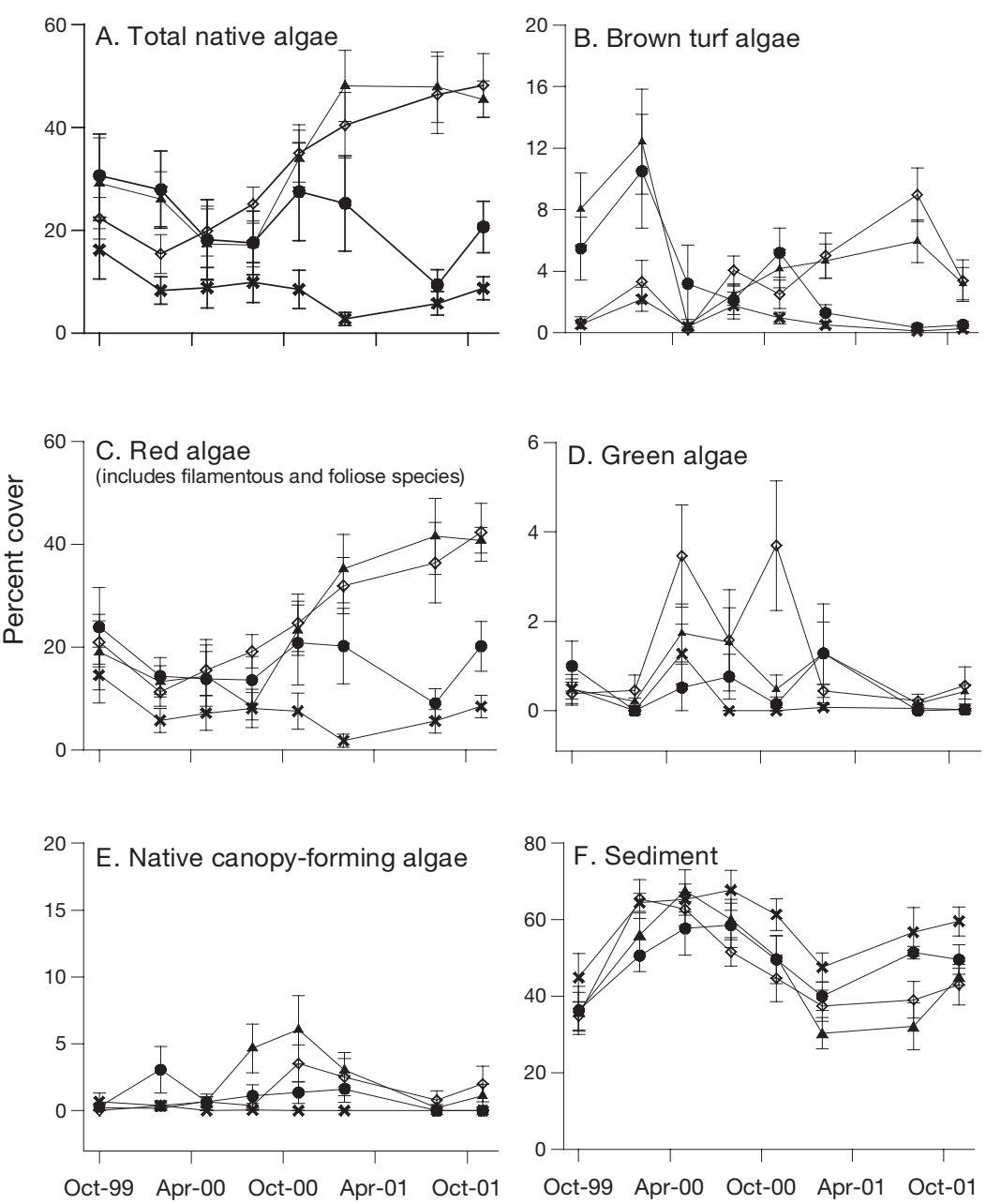

Fig. 4. Effect of experimental manipulations on cover of various algal guilds and sediment. Data represent mean $( \pm \mathrm{SE})$ percentage cover $(\mathrm{n}=8$ replicates per tment) determined from 5 randomly positioned $0.10 \mathrm{~m}^{2}$ photoquadrats
within each experimental plot. Note the different scales on the $y$-axes

$>50 \%$ across all treatments. In November 2001, the cover of sediment was slightly lower in sea urchin removal plots (Fig. 4, Table 3). Although statistically significant, it is likely that this difference was due to the increase in filamentous red algae that occurred in sea-urchin removal plots, which colonised the surface of the sediment matrix rather than replacing the sediment itself. In plots containing sea urchins, the depth of sediment was significantly lower (2-way ANOVA, $F=18.84, \mathrm{df}=1,28, \mathrm{p}=0.001$ ) than in plots from which the urchins were removed $(3.8 \mathrm{~mm} \pm 0.74 \mathrm{SE}$ in removal plots, $1.4 \mathrm{~mm} \pm 0.32 \mathrm{SE}$ in unmanipulated plots) (Fig. 5). Removal of the Undaria pinnatifida canopy had no detectable effect on either the cover or depth of sediment. 
Table 3. Heliocidaris erythrogramma and Undaria pinnatifida. Effect of experimental manipulations on cover of algal guilds at the November 2000 and November 2001 assessments (18 and 30 mo, respectively after manipulations commenced). Results are of the overall ANOVA examining the effect of sea urchin and $U$. pinnatifida removal. Significant p-values $(\alpha=0.05)$ are shown in boldface. Transformations are expressed in terms of the untransformed variable, $Y$

\begin{tabular}{|c|c|c|c|c|c|c|c|c|}
\hline \multirow[t]{3}{*}{ Guild (transformation) } & \multicolumn{8}{|c|}{ Source of variation } \\
\hline & \multicolumn{2}{|c|}{ Urchin } & \multicolumn{2}{|c|}{ Undaria } & \multicolumn{2}{|c|}{ Urchin $\times$ Undaria } & \multicolumn{2}{|c|}{$\begin{array}{c}\text { Plot } \\
(\text { Urchin } \times \text { Undaria })\end{array}$} \\
\hline & $\begin{array}{l}F \\
(\mathrm{df}\end{array}$ & $\begin{array}{r}\quad p \\
=1,28)\end{array}$ & $\begin{array}{l}F \\
(\mathrm{df}=\end{array}$ & $\begin{array}{c}\mathrm{p} \\
1,28)\end{array}$ & $\begin{array}{c}F \\
(\mathrm{df}=\end{array}$ & $\begin{array}{c}\mathrm{p} \\
1,28)\end{array}$ & $\begin{array}{c}F \\
(\mathrm{df}=\end{array}$ & $\begin{array}{c}p \\
28,128)\end{array}$ \\
\hline \multicolumn{9}{|l|}{ November 2000} \\
\hline Total native algae $(\sqrt{Y})$ & 12.66 & $<0.001$ & 2.12 & 0.157 & 2.62 & 0.117 & 5.45 & $<0.001$ \\
\hline Red algae $[\ln (Y+0.1)]$ & 12.35 & 0.002 & 1.07 & 0.310 & 1.73 & 0.199 & 3.67 & $<0.001$ \\
\hline Native canopy-forming algae $(\arcsin \sqrt{0.01 \times} Y)$ & 7.37 & 0.011 & 1.63 & 0.213 & 0.15 & 0.704 & 3.00 & $<0.001$ \\
\hline 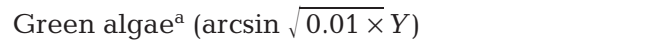 & 7.30 & 0.012 & 4.20 & 0.050 & 5.10 & 0.032 & 0.83 & 0.704 \\
\hline Brown turf algae $^{\mathrm{a}}(\arcsin \sqrt{0.01 \times} Y)$ & 0.05 & 0.823 & 6.88 & 0.014 & 1.30 & 0.264 & 1.06 & 0.395 \\
\hline Sediment (no transformation) & 2.12 & 0.1562 & 0.30 & 0.558 & 2.45 & 0.1286 & 3.82 & $<0.001$ \\
\hline \multicolumn{9}{|l|}{ November 2001} \\
\hline Total native algae $\left(Y^{0.42}\right)$ & 56.06 & $<0.001$ & 2.50 & 0.125 & 3.38 & 0.077 & 3.03 & $<0.001$ \\
\hline Red algae $(\sqrt{Y})$ & 49.14 & $<0.001$ & 3.05 & 0.092 & 2.80 & 0.106 & 2.59 & $<0.001$ \\
\hline Native canopy-forming algae $(\arcsin \sqrt{0.01 \times} Y)$ & 3.94 & 0.057 & 0.32 & 0.577 & 0.32 & 0.577 & 1.55 & 0.053 \\
\hline 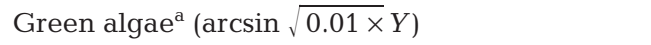 & 4.49 & 0.043 & 0.10 & 0.760 & 0.09 & 0.762 & 0.95 & 0.539 \\
\hline Brown turf algae $^{\mathrm{a}}(\arcsin \sqrt{0.01 \times} Y)$ & 11.38 & 0.002 & 0.00 & 0.963 & 0.06 & 0.805 & 1.47 & 0.080 \\
\hline Sediment (no transformation) & 7.28 & 0.012 & 0.95 & 0.339 & 2.43 & 0.130 & 2.10 & 0.003 \\
\hline
\end{tabular}

Table 4. Heliocidaris erythrogramma and Undaria pinnatifida. Effect of experimental manipulations on biomass of algal guilds collected at the end of the experiment (November 2001). Results are of the overall ANOVA examining the effect of sea urchin and $U$. pinnatifida removals. Significant p-values $(\alpha=0.05)$ are shown in boldface. Note that for the response of $U$. pinnatifida, the table includes the results of a 1-way ANOVA on the effect of urchin removal, as it was not appropriate to examine the effect of U. pinnatifida canopy removal on U. pinnatifida biomass

\begin{tabular}{|c|c|c|c|c|c|c|}
\hline \multirow{4}{*}{$\begin{array}{l}\text { Algal guild (transformation) } \\
\text { Total native algal cover }[\ln (Y+0.1)]\end{array}$} & \multicolumn{6}{|c|}{ Source of variation } \\
\hline & \multicolumn{2}{|c|}{ Urchin } & \multicolumn{2}{|c|}{ Undaria } & \multicolumn{2}{|c|}{ Urchin $\times$ Undaria } \\
\hline & \multicolumn{2}{|c|}{${ }^{F}{ }_{(\mathrm{df}=1,28)}^{p}$} & \multicolumn{2}{|c|}{$\begin{array}{l}F \quad p \\
(\mathrm{df}=1,28)\end{array}$} & \multicolumn{2}{|c|}{$\begin{array}{l}F \quad p \\
(\mathrm{df}=1,28)\end{array}$} \\
\hline & 52.97 & $<0.001$ & 0.20 & 0.658 & 0.87 & 0.358 \\
\hline Undaria pinnatifida (no transformation) & 6.98 & 0.019 & & & & \\
\hline Native canopy-forming algae ${ }^{\mathrm{a}}[\ln (Y+0.1)]$ & 7.26 & 0.012 & 0.16 & 0.693 & 0.16 & 0.693 \\
\hline Foliose red algae $\left(Y^{0.32}\right)$ & 42.76 & $<0.001$ & 0.29 & 0.595 & 1.58 & 0.220 \\
\hline Brown turf algae $\left(Y^{0.14}\right)$ & 58.83 & $<0.001$ & 0.07 & 0.798 & 0.23 & 0.633 \\
\hline
\end{tabular}

A prominent feature of the sediment matrix during summer 2001 was the presence of a cyanobacterial mat, dominated by the rod-forming species Microcoleus spp. Although the extent of the cyanobacterial mat was not affected by experimental manipulations, across all treatments, an average of $25 \%$ of the sediment was colonised by this organism.

\section{Spatial variability of algal guilds}

A feature of the analysis associated with cover of the various algal guilds was the consistent significance of the 'plot (urchin $\times$ Undaria)' term (Table 3), indicating development of different algal communities in replicate plots of the same treatment. Given that replicate 


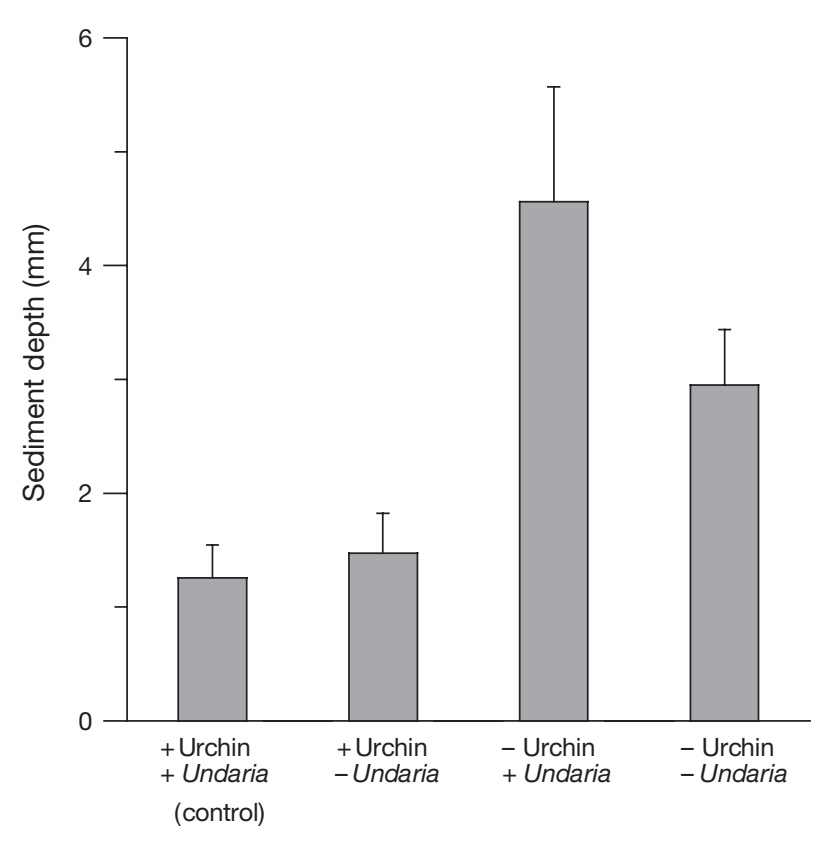

Fig. 5. Effect of experimental manipulations on sediment depth, assessed in November 2001. Data represent mean $(+\mathrm{SE})$ depth $(\mathrm{n}=8$ replicates per treatment) determined from 5 random positions within each experimental plot

plots were separated by a range of 15 to $180 \mathrm{~m}$, this result reflects patchiness in the cover of algae at this spatial scale.

\section{DISCUSSION}

In assessing the threat Undaria pinnatifida poses to native algal communities, it is essential to identify the factor(s) that underpin(s) the persistence of this introduced species. Alternative scenarios may explain long-term persistence of $U$. pinnatifida on sea urchin barrens. Firstly, persistence of dense $U$. pinnatifida stands may require continuous intervention by agents (e.g. sea urchin grazing) to restrict the development of native algal competitors. Alternatively, once established, dense $U$. pinnatifida stands may be self-maintaining in the absence of sea urchin grazing or other mechanisms that limit cover of native algae. Self-maintenance could occur if the $U$. pinnatifida canopy inhibits recruitment of native canopy-forming species (e.g. Ambrose \& Nelson 1982, Chapman et al. 2002). This may be further compounded if the dispersal capacity of native canopyforming species is poor (Anderson \& North 1966, Amsler \& Searles 1980, Schiel \& Foster 1986, Santelices 1990, Fletcher \& Callow 1992). The experimental approach used in this study incorporates manipulations of disturbance (i.e. grazing by sea urchins), the level of $U$. pinnatifida canopy and the level of native algal propagule supply, providing key insights into the persistence of the 'sea urchin barren/U. pinnatifida' community state.

\section{Does persistence of Undaria pinnatifida depend on grazing intensity?}

While sea urchins have previously been observed to graze Undaria pinnatifida sporophytes (Sanderson \& Barrett 1989), the dramatic consequences of sea urchin grazing seen in 2001, where $U$. pinnatifida plants were only recorded in sea urchin removal plots, was unexpected. It is likely that this response was caused either by an increase in grazing intensity by Heliocidaris erythrogramma, decreased recruitment success of $U$. pinnatifida or a combination of both.

While no significant change in Heliocidaris erythrogramma density occurred in the present study in control areas, it is possible that a change in urchin behaviour in response to variation in food availability led to increased grazing pressure on Undaria pinnatifida. If drift algae are the predominant food source of this species of sea urchin (Connolly 1986, Constable 1989), then it is possible that a decrease in drift algae could result in $H$. erythrogramma grazing $U$. pinnatifida at greater intensity during the course of the study. When it was present, sea urchins were observed feeding on drift algae on the urchin barren.

Another explanation for the observed decline in Undaria pinnatifida is variable recruitment success. Our removals of the $U$. pinnatifida canopy show that abundance of $U$. pinnatifida was significantly lower in 2001 than in the previous 2 yr (Table 2). Under these conditions, $U$. pinnatifida abundance could be reduced significantly, while the grazing rate of Heliocidaris erythrogramma remains unchanged. Clearly, lower recruitment success combined with a higher grazing rate would result in an even greater impact on the abundance of $U$. pinnatifida sporophytes.

Our results show that when grazing pressure is low (i.e. in sea urchin removal plots), Undaria pinnatifida and understorey native species recruit successfully. When grazing pressure is high and/or $U$. pinnatifida recruitment is reduced, as occurred in treatments where sea urchin densities were not manipulated in 2001, all algae including $U$. pinnatifida are grazed destructively. Importantly, it appears that when grazing intensity is at an intermediate level between these 2 extremes, $U$. pinnatifida persists while native algal species do not. It is likely that recruitment and growth rates of $U$. pinnatifida are much higher than those of native species, so that $U$. pinnatifida is able to outstrip the capacity to be consumed by the urchin. The feeding preferences of Heliocidaris erythrogramma for $U$. pinnatifida relative to native algae are unknown. 
Grazing preference of sea urchins has previously been suggested to be an important mechanism regulating stands of introduced algae. In the northwest Atlantic, the sea urchin Stronglyocentrotus droebachiensis can consume the introduced alga Codium fragile; however, the alga lacks chemical attractants present in native algae (Laminaria spp.), which are the preferred food source (Prince \& LeBlanc 1992, Scheibling \& Anthony 2001). Based on laboratory feeding preference experiments, it is suggested that in moderate densities, urchins will graze native species creating a mosaic of barren and C. fragile-dominated areas, while at higher urchin densities, all seaweeds will be grazed destructively (Scheibling \& Anthony 2001). Similar experiments to elucidate feeding preference of Heliocidaris erythrogramma would be useful in understanding the patterns of Undaria pinnatifida abundance that we have observed.

\section{Why did canopy-forming species fail to recover?}

A key point is that, under conditions of low grazing pressure, inhibition of Undaria pinnatifida by native algae was not observed because a dense canopy of native algal species did not develop, even after 30 mo of sea urchin removals. This is in contrast to the rapid recovery (typically within $12 \mathrm{mo}$ ) of native canopyspecies observed in other studies in response to removal of sea urchins from 'barrens' habitat (Chapman 1981, Andrew \& Choat 1982, Keats et al. 1990, Leinnas \& Christie 1996, Agatsuma et al. 1997). Moreover, removing both sea urchins and $U$. pinnatifida, as well as providing an immediate source of fertile material, resulted in a maximum of only $6 \%$ cover of native canopy-forming species and a final cover of $2 \%$ after 30 mo of manipulations. Several explanations may account for this limited recovery, related to factors inhibiting supply of algal propagules or post-settlement processes that may have inhibited early developmental stages.

The failure of the spore-enhancement treatment to initiate development of native algae in the absence of sea urchins and Undaria pinnatifida poses several questions. Although the technique has been used successfully elsewhere (Dayton et al. 1984), it is possible that our treatment was unsuccessful in delivering high densities of propagules to the substratum. Although we selected plants with fertile material, the presence of fertile material does not guarantee that propagules will reach the substratum in high densities.

Whether or not the spore enhancement was effective in delivering high densities of spores to the substrate, it is likely that propagules of native canopy-forming species reached the reef via natural dispersal. A number of observations support this view. Firstly, on several occasions throughout the study, large quantities of drift plants (predominately Phyllospora comosa and Ecklonia radiata) were swept onto the barren, often bearing fertile tissue. Secondly, dispersal of propagules from plants in shallow water (10 to $30 \mathrm{~m}$ from experimental plots) is likely. Dispersal from a shallow fringe, where macroalgae have refuge from sea urchin grazing, has been attributed to the rapid recovery of kelp beds on barren grounds in the northwest Atlantic following mortality of sea urchins (Scheibling 1986, Johnson \& Mann 1988, 1993). Finally, although it is widely held that effective dispersal by large brown algae is limited to within a few metres of the parent plants (Dayton 1985, Schiel \& Foster 1986, Santelices 1990, Norton 1992), long-distance dispersal may occur generally, particularly if propagule release coincides with storms and associated turbulent mixing (Reed et al. 1988). More recently, a modelling approach has demonstrated a much greater potential for long-range dispersal in kelps, suggesting that dispersal distance is determined more by processes related to fluid dynamics rather than the biological characteristics of propagules, particularly under conditions of high flow and large waves (Gaylord et al. 2002). Even under calm conditions, $50 \%$ of spores of the kelp Macrocystis pyrifera were predicted to disperse further than $100 \mathrm{~m}$ (Gaylord et al. 2002). Consequently, it is likely that dispersal to the study site from nearby (ca. $100 \mathrm{~m}$ distance) stands of Ecklonia radiata would have occurred during the 30 mo study period.

Intrusion of sea urchins in 2001

The unexpected immigration of Heliocidaris erythrogramma into urchin removal plots in 2001 may have impacted canopy-forming species. It is possible that during the brief incursion of urchins, their grazing may have sufficiently affected native canopy-forming species to prevent recovery. We suggest, however, that this is unlikely given that prior to the incursion, there was a period of 18 mo where the densities of sea urchins remained low, while there was little recruitment of native species. During the period when urchins were at low levels, we observed significant recruitment of native canopy-forming species at an adjacent site (Valentine \& Johnson 2003), indicating that conditions were suitable for macroalgal growth. We note that in similar experiments conducted elsewhere, significant recruitment of large brown algae has occurred in the initial 12 mo following urchin removal (Chapman 1981, Andrew \& Choat 1982, Keats et al. 1990, Leinnas \& Christie 1996, Agatsuma et al. 1997). It is also noteworthy that the increase in under- 
storey algae occurred during the period of urchin intrusion, indicating that sea-urchin grazing was not sufficient to prevent establishment of macroalgae.

Inhibition by understorey algae and the effects of depth

While understorey algae can inhibit recruitment of canopy-forming species (Dayton et al. 1984, Kennelly 1987, Airoldi 1998), total cover of understorey species never exceeded $50 \%$ in the present study and was usually much lower. Thus, it is unlikely to account for the limited recovery of canopy species. The depth of our experimental removals ( 7 to $12 \mathrm{~m}$ ) may have influenced the response of native canopy-forming species. Experimental removal of sea urchins in a New Zealand study has demonstrated that colonisation of large brown algae was much slower in a deeper zone (6.5 to $11.5 \mathrm{~m}$ ) compared with 2 shallower zones (0 to $3.5 \mathrm{~m}$ and 3.5 to $6.5 \mathrm{~m}$ ) (Villouta et al. 2001).

The type of algae that colonises after urchin removal can also be significantly affected by depth. Experimental removal of the sea urchin Centrostephanus rodgersii from barren habitats in New South Wales, Australia showed that shallow ( 1 to $3 \mathrm{~m}$ ) habitats were subsequently dominated by large brown algae (Sargassum spp.), while deeper habitats (7 to $10 \mathrm{~m}$ ) were dominated by filamentous red algae. The absence of brown algae at the deeper site was not due to the decreased light levels since forests of large brown algae were present at similar depths in adjacent areas (Fletcher 1987). Our results parallel some of the findings from Fletcher (1987), in that depth alone does not explain the lack of recovery of canopy-forming species, given that diverse communities dominated by large brown algae are common at similar depths in other regions of the Mercury Passage, including reef within $100 \mathrm{~m}$ of the study site.

\section{Impact of sediment matrix}

The consistently high cover of the sediment matrix, across all treatments, is likely to have contributed to the poor recovery of canopy-forming and other algal species. It is well established that sediment can inhibit recruitment of macroalgae (Devinny \& Volse 1978, Kendrick 1991, Umar et al. 1998). Sediment burial and scour influence algal communities by removing whole organisms, by physically preventing settlement of propagules on stable substrata or by limiting newly settled propagules via reduced inputs of light and oxygen (Airoldi et al. 1995). The depth of the sediment matrix increased significantly after removal of sea urchins in the present study and we observed a similar response following removal of canopy algae in other experiments (Valentine \& Johnson 2003, 2004). It is likely that this was due to increased cover of filamentous algae occurring in the sediment matrix, subsequently facilitating sediment accretion (Melville \& Connell 2001).

The presence of a significant cover of sediment has not been reported from sea-urchin barren habitats elsewhere. Typically, 'sea urchin barrens' are characterised by high cover of crustose coralline algae in association with low macroalgal cover and high seaurchin density, and are often referred to as 'coralline flats' or 'coralline barrens' (Breen \& Mann 1976, Ayling 1981, Jones \& Andrew 1990, Johnson \& Mann 1993, Andrew 1994). The Heliocidaris erythrogramma barren at our study site appears to differ markedly from this general pattern, with only low cover of coralline algae (averaging 9.6\% in control areas) and a high cover of sediment. Indeed, a high accumulation of sediment is a notable general feature of $H$. erythrogramma barrens on the east coast of Tasmania, probably reflecting that these barrens typically arise on sheltered coastal reefs.

\section{CONCLUSIONS}

While our previous experiments clearly demonstrated that disturbance is required for establishment of Undaria pinnatifida (Valentine \& Johnson 2003, 2004), the present study illustrates that persistence of $U$. pinnatifida stands associated with the urchin barren habitat is more complex. While dense stands of $U$. pinnatifida have been observed in the presence of relatively high sea urchin densities (Sanderson \& Barrett 1989, Sanderson 1997, Johnson et al. 2004), our results demonstrate that urchins also have the ability to destructively graze $U$. pinnatifida, eliminating most of the sporophytes in some years. At low sea urchin densities, $U$. pinnatifida persisted despite an increase in understorey algae, suggesting that self-maintenance can occur in the absence of the disturbance (i.e. grazing by sea urchins) that ostensibly enabled $U$. pinnatifida to establish at high densities in the first place. The fact that $U$. pinnatifida persisted in the absence of sea urchins is likely to reflect the poor recovery of native canopy-forming species. While the depth of the barren habitat and limited propagule supply may slow recruitment of canopy-species on the urchin barren, the main factor preventing recovery appears to be the high cover of the sediment matrix. Further research is required to critically investigate the importance of sedimentation as a process inhibiting recovery of canopy-forming native species in these 'urchin barren/U. pinnatifida'-dominated habitats. 
Acknowledgements. We thank the many dive volunteers who assisted with fieldwork operations, particularly E. Forbes, M. Lawler and L. Pietrzykowski. We are particularly grateful to $\mathrm{H}$. Pederson for valuable assistance, both above and below the water, and to 3 anonymous reviewers for constructive comments on the manuscript. This study was part of J.P.V.'s PhD project supported by an Australian Postgraduate Award. Research funds were provided by an ARC grant awarded to C.R.J.

\section{LITERATURE CITED}

Agatsuma Y, Matsuyama K, Nakata A, Kawai T, Nishikawa N (1997) Marine algal succession on coralline flats after removal of sea urchins in Suttsu Bay on the Japan Sea coast of Hokkaido, Japan. Nippon Suisan Gakkaishi 63: $672-680$

Airoldi L (1998) Roles of disturbance, sediment stress, and substratum retention on spatial dominance in algal turf. Ecology 79:2759-2770

Airoldi L, Rindi F, Cinelli F (1995) Structure, seasonal dynamics and reproductive phenology of a filamentous turf assemblage on a sediment influenced, rocky subtidal shore. Bot Mar 38:227-237

Ambrose RF, Nelson BV (1982) Inhibition of giant kelp recruitment by an introduced brown alga. Bot Mar 15: 265-267

Amsler CD, Searles RB (1980) Vertical distribution of seaweed spores in a water column offshore of North Carolina. J Phycol 16:617-619

Anderson EK, North WJ (1966) In situ studies of spore production and dispersal in the giant kelp, Macrocystis. Proc Int Seaweed Symp 5:73-86

Andrew NL (1993) Spatial heterogeneity, sea urchin grazing, and habitat structure on reefs in temperate Australia. Ecology 74:292-302

Andrew NL (1994) Survival of kelp adjacent to areas grazed by sea urchins in New South Wales, Australia. Aust J Ecol 19:466-472

Andrew NL, Choat JH (1982) The influence of predation and conspecific adults on the abundance of juvenile Evechinus chloroticus (Echinoidea: Echinometridae). Oecologia 54: 80-87

Andrew NL, Viejo RM (1998) Ecological limits to the invasion of Sargassum muticum in northern Spain. Aquat Bot 60: 251-263

Ayling AM (1981) The role of biological disturbance in temperate subtidal encrusting communities. Ecology 62: 830-847

Breen PA, Mann KH (1976) Changing lobster abundance and the destruction of kelp beds by sea urchins. Mar Biol 34: $137-142$

Carlton JT (1999) Scale and ecological consequences of biological invasions in the world's oceans. In: Sandlund OT, Schei PJ, Viken A (eds) Invasive species and biodiversity management. Kluwer Academic Publishers, Dordecht, p 195-212

Carlton JT, Geller JB (1993) Ecological roulette: the global transport of nonindigenous marine organisms. Science 261:78-82

Chapman ARO (1981) Stability of sea urchin dominated barren grounds following destructive grazing of kelp in St. Margaret's Bay, eastern Canada. Mar Biol 62:307-311

Chapman ARO, Johnson CR (1990) Disturbance and organization of macroalgal assemblages in the Northwest Atlantic. Hydrobiologia 192:77-121
Chapman AS, Scheibling RE, Chapman ARO (2002) Species introductions and changes in the marine vegetation of Atlantic Canada. In: Claudi R, Nantel P, Muckle-Jeffs E (eds) Alien invaders in Canada's waters, wetlands, and forests. Canadian Forest Service, Natural Resources Canada, Ottawa, p 133-148

Connolly R (1986) Behaviour and ecology of the sea urchin Heliocidaris erythrogramma (Valenciennes). Honours thesis, University of Adelaide

Constable AJ (1989) An investigation of resource allocation in the sea urchin Heliocidaris erythrogramma (Valenciennes). PhD thesis, University of Melbourne

Dayton PK (1985) Ecology of kelp communities. Annu Rev Ecol Syst 16:215-245

Dayton PK, Currie V, Gerrodette T, Keller BD, Rosenthal R, Ven Tresca D (1984) Patch dynamics and stability of some Californian kelp communities. Ecol Monogr 54:253-289

Dethier MN, Graham ES, Cohen S, Tear LM (1993) Visual versus random-point percentage cover estimations: 'objective' is not always better. Mar Ecol Prog Ser 96: 93-100

Devinny JS, Volse IA (1978) The effects of sediments on the development of Macrocystis pyrifera gametophytes. Mar Biol 48:343-348

Deysher L, Norton TA (1982) Dispersal and colonisation in Sargassum muticum (Yendo) Fensholt. J Exp Mar Biol Ecol 56:179-196

Draper N, Smith H (1981) Applied regression analysis. Wiley, New York

Fletcher RL, Callow M (1992) The settlement, attachment and establishment of marine algal spores. Br Phycol J 27: 303-329

Fletcher WJ (1987) Interactions among subtidal Australian sea urchins, gastropods, and algae: Effects of experimental removals. Ecol Monogr 57:89-109

Foster MS, Harrold C, Hardin DD (1991) Point vs. photo quadrat estimates of the cover of sessile marine organisms. J Exp Mar Biol Ecol 146:193-203

Gaylord B, Reed DC, Raimondi PT, Washburn L, McClean SR (2002) A physically based model of macroalgal spore dispersal in the wave and current-dominated nearshore. Ecology 83:1239-1251

Hagen NT (1995) Recurrent destructive grazing of successionally immature kelp forests by green sea urchins in Vestfjorden, Northern Norway. Mar Ecol Prog Ser 123: 95-106

Hiebert RD (1997) Prioritizing invasive plants and planning for management. In: Luken JO, Thieret JW (eds) Assessment and management of plant invasions. SpringerVerlag, New York, p 195-212

Johnson CR, Mann KH (1988) Diversity, patterns of adaptation and stability of Novia Scotion kelp beds. Ecol Monogr 58:129-154

Johnson CR, Mann KH (1993) Rapid succession in subtidal understorey seaweeds during recovery from overgrazing by sea urchins in eastern Canada. Bot Mar 36:63-77

Johnson CR, Valentine JP, Pederson HG (2004) A most unusual barrens: Complex interactions between lobsters, sea urchins and algae facilitates spread of an exotic kelp in eastern Tasmania. In: Heinzeller T, Nebelsick JH (eds) Proceedings of the 11th International Echinoderm Conference, Munich, 6-10 October 2003, Rotterdam. Balkema, Leiden

Jones GP, Andrew NL (1990) Herbivory and patch dynamics on rocky reefs in temperate Australasia: the roles of fish and sea urchins. Aust J Ecol 15:505-520

Keats DW, Robin South G, Steele DH (1990) Effects of experi- 
mental reduction in grazing by green sea urchins on a benthic macroalgal community in eastern Newfoundland. Mar Ecol Prog Ser 68:181-193

Kendrick GA (1991) Recruitment of coralline crusts and filamentous turf algae in the Galapagos archipelago: effect of simulated scour, erosion and accretion. J Exp Mar Biol Ecol 147:47-63

Kennelly SJ (1987) Physical disturbances in an Australian kelp community. I. Temporal effects. Mar Ecol Prog Ser 40: $145-153$

Leinnas HP, Christie H (1996) Effects of removing sea urchins (Stronglyocentrotus droebachiensis): stability of the barren state and succession of kelp forest recovery in the east Atlantic. Oecologia 105:524-536

Mann KH (1977) Destruction of kelp beds by sea urchins: a cyclical phenomenon or irreversible degradation? Helgol Wiss Meeresunters 30:455-467

Meese RJ, Tomich PA (1992) Dots on the rocks: a comparison of percent cover estimation methods. J Exp Mar Biol Ecol 165:59-73

Meinesz A, de Vaugelas J, Hesse B, Mari X (1993) Spread of the introduced tropical green alga Caulerpa taxifolia in northern Mediterranean waters. J Appl Phycol 5:141-147

Melville AJ, Connell SD (2001) Experimental effects of kelp canopies on subtidal coralline algae. Austral Ecol 26:102-108

Nichols FH, Thompson JK, Schemel L (1990) Remarkable invasion of San Francisco Bay (California, USA) by the Asian clam Potamocorbula amurensis. II. Displacement of a former community. Mar Ecol Prog Ser 66:95-101

Norton TA (1992) Dispersal by macroalgae. Br Phycol J 27: 293-301

Palacin C, Giribet G, Carner S, Dantart L, Turon X (1998) Low densities of sea urchins influence the structure of algal assemblages in the Western Mediterranean. J Sea Res 39: 281-290

Prince JS, LeBlanc WG (1992) Comparative feeding preference of Stronglyocentrotus droebachiensis (Echinoidea) for the invasive seaweed Codium fragile ssp. tomentosoides (Chlorophyceae) and four other seaweeds. Mar Biol 113:159-163

Reed DC, Laur DR, Ebeling AW (1988) Variation in algal dispersal and recruitment: the importance of episodic events. Ecol Monogr 58:321-335

Reusch TBH, Williams SL (1999) Macrophyte canopy structure and the success of an invasive marine bivalve. Oikos 84:398-416

Ribera MA, Boudouresque C (1995) Introduced marine

Editorial responsibility: Otto Kinne (Editor-in-Chief),

Oldendorf/Luhe, Germany plants, with special reference to macroalgae: mechanisms and impact. In: Round FE, Chapman DJ (eds) Progress in phycological research, Vol 11. Biopress Ltd, Marine Environmental Systems, Hobart, p 217-268

Sanderson JC (1997) Survey of Undaria pinnatifida in Tasmanian coastal waters, January-February 1997. Report to Tasmanian Department of Marine Resources. Marine Environmental Systems, Hobart

Sanderson JC, Barrett N (1989) A survey of the distribution of the introduced Japanese macroalga Undaria pinnatifida (Harvey) Suringer in Tasmania, December 1988. Report No. 38, Department of Sea Fisheries, Hobart

Sanderson JC, Le Rossignol M, James W (1996) A pilot program to maximise Tasmania's sea urchin (Heliocidaris erythrogramma) resource. Marine Environmental Systems, Hobart

Santelices B (1990) Patterns of reproduction, dispersal and recruitment in seaweeds. Oceanogr Mar Biol Annu Rev 28:177-276

Scheffé H (1959) The analysis of variance, Wiley, New York

Scheibling RE (1986) Increased macroalgal doundance following mass mortalities of sea urchins (Stronglyocentrotus droebachiensis) along the Atlantic coast of Nova Scotia. Oecologia 68:186-198

Scheibling RE, Anthony SX (2001) Feeding, growth and reproduction of sea urchins (Stronglyocentrotus droebachiensis) on single and mixed diets of kelp (Laminaria spp.) and the invasive alga Codium fragile ssp. tomentosoides. Mar Biol 139:139-146

Schiel DR, Foster MS (1986) The structure of subtidal algal stands in temperate waters. Oceanogr Mar Biol Annu Rev 24:265-307

Umar MJ, McCook LJ, Price IR (1998) Effects of sediment deposition on the seaweed Sargassum on a fringing coral reef. Coral Reefs 17:169-177

Valentine JP, Johnson CR (2003) Establishment of the introduced kelp Undaria pinnatifida in Tasmania depends on disturbance to native algal assemblages. J Exp Mar Biol Ecol 265:63-90

Valentine JP, Johnson CR (2004) Establishment of the introduced kelp Undaria pinnatifida following dieback of the native macroalga Phyllospora comosa in Tasmania, Australia. Mar Freshw Res 55:1-8

Villouta E, Chadderton WL, Pugsley CW, Hay CH (2001) Effects of sea urchin (Evechinus chloroticus) grazing in Dusky Sound, Fiordland, New Zealand. NZ J Mar Freshw Res 35:1007-1024

Submitted: May 6, 2003; Accepted: August 19, 2004

Proofs received from author(s): January 5, 2005 